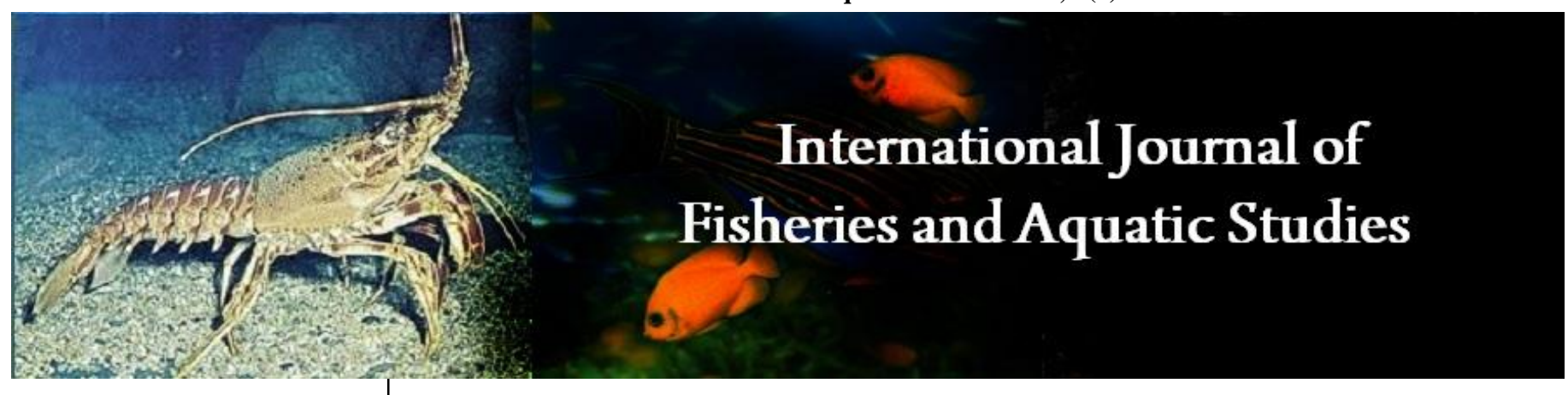

E-ISSN: 2347-5129

P-ISSN: 2394-0506

(ICV-Poland) Impact Value: 5.62

(GIF) Impact Factor: 0.549

IJFAS 2021; 9(4): 139-141

(C) 2021 IJFAS

www.fisheriesjournal.com

Received: 22-05-2021

Accepted: 24-06-2021

Dian Yuni Pratiwi

Faculty of Fisheries and Marine

Science, Universitas

Padjadjaran; Indonesia

Fittrie Meyllianawaty Pratiwy Faculty of Fisheries and Marine

Science, Universitas

Padjadjaran; Indonesia

\section{Effect of fermented water hyacinth (Eichhornia crassipes) on growth performance of fish}

\author{
Dian Yuni Pratiwi and Fittrie Meyllianawaty Pratiwy
}

DOI: https://doi.org/10.22271/fish.2021.v9.i4b.2533

\section{Abstract}

Water hyacinth is an aquatic plant, which can grow rapidly along the water area with rich of nutrients. Mostly this plant can be the alternative ingredient for fish feed because it contains various nutrients such as proteins, carbohydrates, lipids, minerals, amino acids, fatty acids, secondary metabolites. However, because it plant-based, it rich of fiber and anti-nutritional factors such as tannins and phytic acids which can degrade the quality of fish feed and decrease the growth performance of fish if used in high concentration. Water hyacinth fermentation can be a solution to increase digestibility and nutrient contents. Several studies showed that growth performance of fish fed by fermented water hyacinth better than non-fermented. The concentration, which can apply as feed ingredient, ranged 20-40\% replacement.

Keywords: water hyacinth, Eichhornia, fermented feed, feed fish, growth performance

\section{Introduction}

The global fish demand is currently increasing, and even higher than for crustaceans, mollusks, sea urchins, and turtles. Fish market share in 2020 will reach $30.19 \%{ }^{[1]}$. The amount of global fish consumption from 1961-2017 was increased by $3.1 \%$ per year. Fish consumption per capita in 1961 was $9.0 \mathrm{~kg}$. In 2017, fish consumption per capita was $20.3 \mathrm{~kg}$ and $20.5 \mathrm{~kg}$ in $2018^{[2]}$.

Fish farming is one way to meet consumer demand apart from capture fisheries. Aquaculture production in 2018 reached 82 million ${ }^{[2]}$. One of the factors that influence the success of aquaculture is the availability of quality fish feed. This is because about $50-70 \%$ of production costs are for feed costs. In addition, the quality of feed will determine the growth of fish that are cultivated. The better the quality of the feed, the more significant it will be for the growth of fish. However, the price of feed raw materials, especially raw materials as a source of protein such as fish oil and fish meal varies and tends to increase [3], and the amount of production of these materials also varies ${ }^{[2]}$. This encourages aquaculture business actors to find a way to cost-effective feed. There are four things to streamline production costs, namely 1) reducing the amount of fish meal and fish oil used in fish feed, 2) choosing types of fish that require low protein and lipids, 3) formulating environmentally friendly feeds, 4) formulating feeds with natural ingredients-sustainable raw materials ${ }^{[4]}$. Therefore, many researchers are finding alternative feed ingredients that are cheaper and have a positive effect on growth.

One of the alternative raw materials that can be used is water hyacinth ${ }^{[5]}$. Water hyacinth is an aquatic plant that contains various nutrients such as proteins, carbohydrates, lipids and so on [6]. This plant can grow quickly and uncontrollably in nutrient-rich waters, so this plant was identified as one of the 100 most aggressive invasive species by The International Union for Conservation of Nature (IUCN) ${ }^{[7]}$. Water hyacinth blooms in waters have various negative impacts, including covering the water surface, blocking canals and waterways, habitat for mosquitoes, blocking fishing, hampering water transportation, reducing the number of fish in the water ${ }^{[8]}$. If water hyacinth is used as a raw material for fish feed, it is expected to be a solution to the availability of cheap alternative raw materials for fish feed as well as a solution to water hyacinth blooming.

However, another challenge is that water hyacinth contains high levels of fiber and antinutritional factors such as tannin and phytic acid, thereby reducing digestibility and absorption
Corresponding Autho
Dian Yuni Pratiwi

Faculty of Fisheries and Marine

Science, Universitas

Padjadjaran; Indonesia 
of nutrients. Therefore, water hyacinth fermentation for fish feed raw materials needs to be carried out. Fermentation is an inexpensive process to reduce fiber content and increase nutrient content. Fermentation can also be used to remove anti-nutritional factors ${ }^{[9]}$.

This review article aims to describe the nutritional content of fermented and unfermented water hyacinth, and the effect of fermented water hyacinth on the growth performance of several types of fish.

\section{Chemical Composition of Fermented and Nonfermented Water Hyacinth (Eichhornia crassipes)}

Water hyacinth, a perennial plant belonging to the Pontederiaceae family. This plant which originating from North America can live in shallow freshwater waters such as ponds, lakes, canals. Each flower has 6 petals which are solid lilac in color with the top petal bluish with a bright yellow dot. The fruit is a three celled capsule containing many seeds ${ }^{[10]}$. Water hyacinth has a wide environmental tolerance. It can live at a temperature of $28-30{ }^{\circ} \mathrm{C}, \mathrm{pH}$ ranges from $6-8$, and salinity below $1.6 \%{ }^{[11]}$.

Water hyacinth contains many nutrients such as proteins, carbohydrates, lipids, minerals, amino acids, fatty acids, secondary metabolites ${ }^{[12]}$. Secondary metabolites contained in water hyacinth include alkaloids, saponins, steroidal compounds, flavonoids, phenolic compounds, glycosides, and cardiac glycosides ${ }^{[13]}$. Water hyacinth also contains high levels of fiber and anti-nutritional factors such as tannins and phytic acids. The fiber content and anti-nutritional factors can interfere digest proccess in fish. Tannins can inhibit the activity of proteases and other digestive enzymes. Phytic acid can reduce protein and mineral bioavailability ${ }^{[14]}$.

Water hyacinth fermentation can be a solution to increase digestibility and nutrient content ${ }^{[9]}$. Comparison of protein content, lipid content, and fiber content of fermented and nonfermented water hyacinth from various references can be seen in Table 1. While the content of various fibers in nonfermented and fermented water hyacinth can be seen in Table 2.

Table 1: Chemical Composition of fermented and nonfermented water hyacinth (\% dw)

\begin{tabular}{|c|c|c|c|c|c|}
\hline No & Parameters & Protein & Lipid & Fiber & Reference \\
\hline \multirow{4}{*}{1} & Non Fermented & 21.1 & 1.0 & 19.0 & \multirow{4}{*}{ [15] } \\
\hline & Molasse-Fermented & 19.8 & 0.4 & 16.3 & \\
\hline & Rumen Fermented & 18.2 & 0.7 & 17.3 & \\
\hline & Yeast Fermented & 18.1 & 0.5 & 16.2 & \\
\hline \multirow{3}{*}{2} & Non Fermented & 13.37 & 1.0 & 15.0 & \multirow{3}{*}{ [14] } \\
\hline & Fermented By B. Megaterium Ci3 & 14.44 & 1.5 & 1 & \\
\hline & Fermented By B. Subtilis Cy $5+$ Lactobacillus acidophilus & 16.88 & 12.0 & 13.5 & \\
\hline \multirow{2}{*}{3} & Non Fermented & 6.31 & 2.83 & 26.61 & \multirow{2}{*}{ [16] } \\
\hline & Fermented by Trichoderma Harzianum & 10.21 & 2.99 & 21.81 & \\
\hline
\end{tabular}

Table 2: The fiber content in fermented and nonfermented water hyacinth (\% DW)

\begin{tabular}{|c|c|c|c|c|c|}
\hline No & Parameter & Cellulose & Hemicellulose & Lignin & Reference \\
\hline \multirow{2}{*}{1} & Non fermented & 24.61 & 21.14 & 3.35 & \multirow{2}{*}[16]{} \\
\cline { 2 - 5 } & Fermented by Trichoderma Harzianum & 31.09 & 12.43 & 2.18 & \\
\hline \multirow{3}{*}{2} & Non Fermented & 11.40 & 0.15 & - & \multirow{2}{*}[14]{} \\
\cline { 2 - 5 } & Fermented By B. Megaterium Ci3 & 7.65 & 0.06 & - & \\
\cline { 2 - 5 } & Fermented By B. Subtilis Cy5 + Lactobacillus acidophilus & 5.80 & 0.10 & - & \\
\hline
\end{tabular}

\section{The Utilization of Fermented Water Hyacinth (Eichhornia Crassipes) as Fish Feed Ingredient}

Researchers have shown that fermented water hyacinth has a positive effect on the growth of several types of fish. Sadique et.al (2018) ${ }^{[9]}$ have investigated the effect of molassesfermented water hyacinth feed in various concentrations $(10$, $20,30,40 \%$ ) on the growth and body composition of the common carp, Cyprinus carpio. The results showed that the weight gain of carp fed with fermented water hyacinth was higher than fish that not fed with fermented water hyacinth. The weight gain of carp increased along with the increase in the concentration of fermented water hyacinth given to the feed. In addition, the highest protein and lipid content was found in carp fed $40 \%$ fermented water hyacinth. While the highest carbohydrate content was obtained in carp that was fed $20 \%$ fermented water hyacinth. Fermented water hyacinth can partially replace conventional energy sources in the compound diet of common carp.

The weight of river carp (Leptobarbus hoevenii) fingerling given with fermented water hyacinth for 56 days was heavier than fish that was not given fermented water hyacinth. The protein retention of river carp fish fed with $30 \%$ fermented water hyacinth flour was $17.80 \%$. This value was higher than protein retention in fish that were not given fermented water hyacinth which was only $(7.05 \%)^{[17]}$. Protein retention states the amount of protein stored and made into new body tissue by fish during maintenance $\left.{ }^{[18}\right]$. This indicates that the fish fed fermented water hyacinth have been able to utilize the protein in the feed optimally ${ }^{[17]}$.

Saha and Ray (2011) ${ }^{[14]}$ have researched on the effect of giving fermented water hyacinth to Rohu fish, Labeo rohita (Hamilton, 1822) Fingerlings. Fermentation were carried out using Bacillus megaterium CI3, and fermentation with Bacillus subtilis CY5 + Lactobacillus acidophilus. The results showed that the highest weight gain of Rohu fish, L. rohita (Hamilton, 1822) fingerlings was obtained in fish given $20 \%$ fermented water hyacinth with $B$. megaterium $\mathrm{CI} 3$ which was $7.19 \%$. The second highest weight gain was found in fish fed $20 \%$ fermented water hyacinth with B. subtilis CY5 $+L$. acidophilus which was $7.09 \%$. The lowest weight gain was found in fish fed $40 \%$ raw water hyacinth leaf meal, which was $6.42 \%$. The highest protein digestibility value was obtained at $30 \%$ water hyacinth fermented with $B$. megaterium $\mathrm{CI} 3$ ). High protein digestibility indicates that the feed is of good quality and feed protein can be utilized efficiently by fish to maintain basal metabolism and for production purposes ${ }^{[19]}$. In another study using grass carp 
(Ctenopharyngodon idella), nutrient digestibility in feed containing fermented water hyacinth is also higher than the digestibility of nonfermented water hyacinth feed which is $66.72 \%$ compared to $63.49 \%{ }^{[20]}$. From these two studies, fish feed containing fermented water hyacinth was more efficient for use by fish. Digestibility is an indicator to determine the ability of fish to digest the feed given. If the digestibility value of a feed is low, it indicates that the feed given cannot be utilized optimally by the fish ${ }^{[17]}$.

\section{Conclusion}

Water hyacinth is water plant, which can growing rapidly and contains high amount of nutrients such as protein, lipids, minerals, amino acids, fatty acids, etc. Alongside with very rich nutrient, the amount of fiber content as well as anti nutrional-factors such as tannins and phytic acids can be the limited factor for this plant to be used as fish feed. Its utilization as fish feed ingredients can be optimized by fermentation process. Previous study showed that fermentation could increase the quality of protein, lipid, amino acids, and decrease the fiber content and antinutritional factors. Mostly, the effective fermentation have been done using lactic acid bacteria such as Bacillus sp. and Lactobacillus sp. Fermented water hyacinth feed based showed positive effect on the growth performance of several species of fish, the utilization can be use up to $40 \%$ of addition. This application need more studies relating with the appropriate concentration of fermented water hyacinth for fish feed in the future.

\section{References}

1. Quick dissolving tablets. https://www.globenewswire.com/newsrelease/2021/06/02/2240869/0/en/Global-AquafeedMarket-Is-Expected-to-Reach-USD-82-05-billion-by2028-Fior-Markets.html. 10 July 2021.

2. FAO. 2020. The State of World Fisheries and Aquaculture 2020. Sustainability in action. Rome.

3. https://doi.org/10.4060/ca9229en. 10 July 2021

4. Terazono E. Fisheries challenged by rising cost of fish oil in feed. 2017. https://www.ft.com/content/651ad4282511-11e7-a34a-538b4cb30025. 10 July 2021

5. Mamauag RE. Promotion of cost-effective aquaculture feed made of locally available feed ingredients. Network of Aquaculture Centres of Asia-Pasific. 2017. https://enaca.org/?id=905

6. Sotolu AO, Sule O. Digestibility and Performance of Water Hyacinth Meal In The Diets Of African Catfish (Clarias gariepinus; Burchell, 1822). Tropical and Subtropical Agroecosystems. 2011;14:245-250

7. Suleiman, Khadija AY, Nasiru Y, Garba AA, Alhassan M, Bello HJ. Proximate, Minerals and Anti-Nutritional Composition of Water Hyacinth (Eichhornia crassipes) Grass. Earthline Journal of Chemical Sciences 2020;3(1):51-59

8. Global Invasive Species Database. http://www.iucngisd.org/gisd/100_worst.php. 10 July 2021.

9. Ndimele PE. The Effects of Water Hyacinth (Eichhornia Crassipes [Mart.] Solms) Infestation on The PhysicoChemistry, Nutrient and Heavy Metal Content of Badagry Creek and Ologe Lagoon, Lagos, Nigeria. Journal Of Environmental Science and Technology. 2021;5:128-136.
10. Sadique K, Pandey J, Khairnar A, SO, Kumar N. Effect of molasses-fermented water hyacinth feed on growth and body composition of common carp, Cyprinus carpio. Journal of Entomology and Zoology Studies. 2018;6(4):1161-1165

11. Quick dissolving tablets http://sfrc.ufl.edu/extension/4h/plants/Water_hyacinth/in dex.html

12. Di Tomaso JM, Healy EA. Aquatic and riparian weeds of the West. University of California. Division of Agriculture and Natural Resources, California Weed Science Society: ANR Publications 2003, 52-55.

13. Adeyemi O. Assessment of nutritional quality of water hyacinth leaf protein concentrate. 2016. The Egyptian Journal of Aquatic Research_2016;42(3):269-272

14. Hossain J, Khan A, Uddin MA. Antimicrobial Efficacy and Phytochemical Analysis of Three Aquatic Plant Species in Bangladesh. Bangladesh J Microbiol 2018;35(1):07-11

15. Saha SB, Ray AK. Evaluation Of Nutritive Value of Water Hyacinth (Eichhornia Crassipes) Leaf Meal In Compound Diets For Rohu, Labeo rohita (Hamilton, 1822) Fingerlings After Fermentation With Two Bacterial Strains Isolated From Fish Gut. Turkish Journal of Fisheries and Aquatic Sciences 2011;11:199-207.

16. El-Sayed AF. Effects of fermentation methods on the nutritive value of water hyacinth for Nile tilapia Oreochromis niloticus (L.) fingerlings. Aquaculture. 2003;218:471-478.

17. Mahmilia F. The Change Of Nutritional Value of The Fermented Eichhornia crassipes Mart Meal As Broiler Rations. Jitv. 2005;10(2):90-95.

18. Rahmad FA, Suharman I, Adelina. Effect of Fermented Water Hyacinth (Eichhornia crassipes) Meal Using A Cow Rumen Fluid in Diets on Growth of River Carp (Leptobarbus hoevenii) Fingerling. Jurnal Online Mahasiswa 2017;4(1)

19. Sonata MA, Sulhi M, Azrita. Substitusi Tepung Kedelai Dengan Tepung Eceng Gondok Hasil Fermentasi Dalam Formulasi Pakan Terhadap Sintasan Dan Pertumbuhan Benih Ikan Gurame (Osphronemus gouramy Lac). Prosiding Forum Inovasi Teknologi Akuakultur 2015, 319-325

20. Muchtaromah B, Susilowati R, Kusumastuti A. Pemanfaatan Tepung Hasil Fermentasi Eceng Gondok (Eichornia crassipes) Sebagai Campuran Pakan Ikan Untuk Meningkatan Berat Badan Dan Daya Cerna Protein Ikan Nila Merah (Oreochromis Sp.). El-Qudwah 2006.

21. Sayed-Lafi RM, Al-Tameemi RA, Gowd et al. Evaluation of raw and fermented water hyacinth (Eichhornia crassipes) incorporated diets on growth and feed efficiency of young grass carp (Ctenopharyngodon idella). Basrah J Agric. Sci 2018;31(1):31-39. 